\title{
1. An introduction to frontiers in pension finance
}

\section{Dirk Broeders, Sylvester Eijffinger and Aerdt Houben}

\subsection{INTRODUCTION}

All over the world, pension systems are being transformed, for several reasons. To begin with, over the next decades, societies will come up against the combined consequence of increased life expectancy and lower fertility rates, making pay-as-you-go pension systems difficult to sustain. Secondly, the 'perfect storm' in the period 2000-2002 highlighted the vulnerability of funded pension systems to adverse financial market developments and showed that funded pension provisions need to be flexible to cope with such shocks. In the third place, many companies have opted to rid themselves of the residual risk of their pension plans, and have shifted it to individuals who may be considered less qualified to manage financial risks.

At the same time, these challenges are met with breakthroughs in pension finance and a better understanding of the many facets of the way pension systems work. Traditional pension paradigms are being revised in tune with an increasing awareness of the implications of an aging society for both labour and financial markets. Financial market integration, innovations in financial instruments and advances in information technology are enhancing the possibilities for efficient risk management. Meanwhile, pension regulation is aiming to align these developments with those in risk management and disclosure. Improved risk assessment, transparency and governance consequently add, not just to the financial soundness of individual institutions, but also to the resilience of the global financial system.

All this raises important questions which were discussed during the conference, 'Frontiers in pension finance and reform'. Three main topics passed in review: (i) recent developments in pension finance and actuarial science, (ii) the institutional design of pension systems, and (iii) international dynamics in pension governance and supervision. These themes are introduced in the next sections. 


\subsection{RECENT DEVELOPMENTS IN PENSION FINANCE AND ACTUARIAL SCIENCE}

In pension finance, a key role is played by the amalgamation of finance and actuarial science, as a direct result of the fact that pension risks have both a financial and an actuarial component. Pension risks arise when pension financing offers insufficient guarantees that the envisaged benefits will be available. This may be due to replacement rate inadequacy at retirement, social security cuts, the risk of outliving one's savings, investment risk and inflation risk (Bodie, 1990).

Pension financing is up against such uncertainties and pension fund trustees need to have a clear and consistent understanding of these risks. Accordingly, assets and liabilities are increasingly disclosed on a mark-tomarket basis. This facilitates professional risk management with modern financial market instruments. It also enhances market discipline and transparency.

However, both Jon Exley and Jeremy Gold argue in this book that market valuation principles can also be used to demonstrate that, in a perfect (Modigliani-Miller) world, financial risk management does not create value. A key issue in this respect is that pension schemes generally contain implicit options which transfer value from one stakeholder to another. For instance, if shareholders have a claim to a potential surplus in the company pension fund, it may be tempting to increase the risk profile of this fund's assets to increase the value of this claim, thereby lowering the value for the fund's beneficiaries. In other words, embedded options potentially misalign the interests of shareholders and employees. Exley thus states that any justification for pension provision will favour simple transparent and non-contingent defined benefit pension plans rather than the complex benefit schemes with embedded options of various forms which are commonly observed.

Furthermore, one can argue that the world is imperfect and that secondorder effects may play an important role in deriving optimal solutions. Gold reasons in Chapter 3 that, in many Anglo-Saxon countries, returns on bonds owned by corporations and individuals are more highly taxed than those on stocks while, for pension plans, stock and bond returns are treated equally. On this assumption, he claims that it is optimal to establish net negative market (beta) exposure in defined benefit pension plans; this challenges conventional wisdom. 


\subsection{INSTITUTIONAL DESIGN OF PENSION SYSTEMS}

After this theoretical background, let us take a look at the design of pension systems. Reviewing the current structures of pension systems in the western world, one immediately sees that they are predominantly pay-asyou-go systems (see, for example, Table 10.1 in this book).

The current predominance of these schemes can be attributed largely to a single historical reason. As prosperity increased after the Second World War, policy makers began to address the financial position of the elderly. It appeared that many workers had not been able to save sufficiently for their old age. As this caused an immediate and urgent need for some form of old age income provision, many governments decided to instal pay-as-you-go schemes, which become active immediately, rather than funded systems which take effect only after one generation has saved up enough retirement capital. Post-war retirees consequently received a windfall gain as they had not contributed to the pay-as-you-go system during their working lives, but still got to enjoy a full benefit during retirement.

The current pay-as-you-go systems, however, now find themselves under considerable pressure, as aging increases the number of benefit recipients relative to the number of active contributors. Moreover, as most economies are dynamically efficient, the rate of return on a funded system, that is, the interest rate, is higher than the implicit rate of return on a pay-as-you-go system, which equals the economic growth rate (Aaron, 1966). For these two reasons alone, numerous authors have pleaded for (partial or gradual) conversion of existing pay-as-you-go systems into funded ones.

However, the earlier discussed windfall gain for the first generation has an important drawback: owing to the resulting Ponzi game nature of a payas-you-go system, the current reform issue is not to be trifled with. After all, the currently working generation contributes to the pay-as-you-go system in the belief that they too will eventually receive a pay-as-you-go benefit from the same system. They are thus accumulating an implicit claim on the subsequent generation. To be politically feasible, any reform scenario should therefore take these claims seriously by solving the problem of who is going to bear the transitional burden.

A number of authors (see, for example, Breyer (1989) and Verbon (1989)) have shown, however, that, whatever option is chosen, the (partial or gradual) replacement of pay-as-you-go by funding cannot be organized in a Pareto-improving way. Nevertheless, reforms seem necessary. In this context, the contribution of Raimond Maurer, Olivia Mitchell and Ralph Rogalla in this book sheds an interesting light on reform possibilities for the current pay-as-you-go pension system for civil servants in the German 
federal state of Hesse. Their analysis assesses the impact of introducing a supplementary tax-sponsored pension fund whose contributions are invested in capital markets and are used to relieve the public budget of a part of future pension payments.

Whereas the regular focus in the aging literature is often on the consequences for the public budget, the contribution of Axel Börsch-Supan, Ismail Düzgün and Matthias Weiss to this book takes a different angle. They focus on the consequences of aging for labour productivity, which has hardly received attention in the literature so far. The productivity of older workers will be an increasing determinant of total labour productivity. The authors come up with two remarkable conclusions. First, it seems that the loss of productivity as employees get older is compensated by the gain in experience. Secondly, they find evidence against the generally accepted hypothesis that work teams perform better when consisting of a mix of young and older workers. Communication within the team seems to be important; younger workers seem to put the elderly under strain, thereby reducing their performance.

Finally, akin to the funding decision is the issue of the optimal design and implementation of a pension contract. The contribution of David Blake deals with this topic. He focuses on the optimal design of defined contribution schemes and provides evidence that the current UK private pension plans are poorly designed. The main point in this chapter is that the commission charges for selling these plans are front-loaded. By contrast, Blake argues that the best way of delivering value in the pension industry is to have charging structures that are simple, fully transparent, performancerelated and non-front loaded.

\subsection{INTERNATIONAL DYNAMICS IN PENSION GOVERNANCE AND SUPERVISION}

Pre-funded pension systems already play an important role in today's economy. According to the OECD Global Pension Statistics, the weighted average of pension fund assets relative to GDP was 88 per cent in 2005 , compared to only 29 per cent in 1987 . Given the projected further aging of populations and the increasing need for pre-funding in pension finance, the ratio of total pension assets to GDP is projected to rise even further in the coming years. This means that pension funds are also likely to have an increasing influence on financial markets. Today, aggregate pension fund assets represent more than 20 per cent of the domestic equity and 10 per cent of the domestic bond market capitalizations in the G10 countries (Visco, 2005). As these percentages are likely 
to go up further, aging may also contribute to the deepening of financial markets, as well as to a stronger role for capital market intermediation (Blommestein, 2001).

Pension funds thus play a far greater role in today's economy, but not only on a macro level. Pension funds also have an important role as financial intermediaries, helping individuals to save for old age and to protect the value of their pensions (Boeri et al., 2006). The stakes for effective supervision have consequently increased considerably. Indeed, the regulation and supervision of pension funds are essential from both the macro and the micro perspective. They should primarily be aimed at guaranteeing a certain benefit level, at reasonable cost without straining financial stability. In this light, the contributions of Gregory Brunner, Richard Hinz and Roberto Rocha, Keith Ambachtsheer, Zvi Bodie and Lans Bovenberg to this book are relevant. Brunner et al. plead for a wider introduction of risk-based supervisory models, arguing that these are better aligned with the needs of efficient capital market operation. The authors arrived at this conclusion after systematically reviewing riskbased supervisory models in Australia, Denmark, Mexico and the Netherlands.

Ambachtsheer subsequently argues that pension providers which deal effectively with agency issues and practise good governance will create more value for their beneficiaries. He shows that US mutual fund participants suffer at least a 1 per cent net return loss per annum on their retirement savings, relative to participants in a pension fund. Bodie argues that, apart from adequate returns, guarantees are also essential to retirement planning, as they are readily understandable for consumers, and therefore reduce the need for costly financial education. His chapter concentrates on methods to manage pension guarantees so as to minimize the cost of shortfall.

Bovenberg takes a broader stance. He argues that an optimal pension contract should be flexible: it should be a defined contribution when participants are young and possess relatively high human capital with which to absorb shocks, while it should gradually be transformed into a defined benefit contract as the participant depletes his stock of human capital over the course of his life. Furthermore, Bovenberg pleads for stand-alone pension funds, arguing that these are an attractive third way between some continental European pay-as-you-go schemes and Anglo-Saxon defined contribution schemes. Moreover, with stand-alone pension funds, companies no longer have a claim to a possible surplus in the fund, so that conflicts of interest between shareholders and pension fund participants (as noted by Exley and Gold) are ruled out. 


\subsection{GENERAL CONCLUSIONS}

The previous sections show that the contributions collected in this volume cover a wide range of topics central to the ongoing debate on pensions. Overall, the common goal is to improve the efficiency and resilience of pension systems. Both are crucial to the sustainability of adequate old age provisions, as well as to stable financial developments. Clearly, these are dynamic issues as pension systems worldwide have to cope with three major challenges.

The first challenge is to quantify and deal with risks in pension funding. The 'perfect storm' at the beginning of this decade is an excellent example underpinning the importance of adequate pricing and, with that, anticipating pension risks. Pension funds should be encouraged to find a marketoriented optimum in terms of risk, return and transparency. In combination with a movement from rule- to principle-based regulation and supervision, as John Ashcroft pointed out during the panel discussion (see Chapter 12), these measures should help bolster the resilience of the pension system to developments such as those at the turn of the century. But this is not the final stage. The pension industry is constantly changing, mainly owing to internationalization, innovative investment methods and increased competition from, among others, insurance companies. Another issue, specifically related to the latter, is the question whether or not the supervision of pension funds and insurance companies should be harmonized, as advocated by Henrik Bjerre-Nielsen during the panel discussion.

The second challenge is to address the implications of the transfer of pension risks to households. As pension savings rise and companies seek to shield their exposure to financial risks, defined contribution schemes are on the rise all over the world. This involves a massive transfer of risks to households that are often less capable of managing those risks. Lusardi and Mitchell (2005) find that fewer than one-fifth of Americans believe they engage in successful retirement planning. It seems therefore that people need assistance in securing adequate personal pension benefits. Financial innovation, progress in information technology and life-cycle saving as well as progress in investment theory can provide benefit plans that are more in line with the preferences of individuals. To achieve all this, it is necessary to improve transparency through more timely and easy-to-understand customer information, as underscored by Dirk Witteveen during the panel discussion.

The third challenge is to find pragmatic solutions to the economic challenges of aging. Over the next few decades, societies will be forced to deal with the combined effect of increased life expectancy and lower fertility rates, as well as the labour market withdrawal of the baby boom generation. 
The challenge lies in ensuring greater, larger and more productive participation in the labour force.

As Lucas Papademos argues, this will have a significant economic impact in many different areas. While aging will have significant implications for economic growth, real interest rates and financial markets, Papademos states that the consequences of aging do not require any changes to the monetary policy framework or to the ECB's focus on price stability. However, it is essential to monitor and analyse carefully the way in which demographic forces, associated financial market developments and pertinent reforms affect the monetary transmission mechanism over time. Furthermore, for governments, the problems associated with aging do require timely policy actions to keep public finances sustainable. Papademos concludes that there is an urgent need to continue to implement appropriate reforms. We hope these conference proceedings will add to this sense of urgency and stimulate a pragmatic approach to reform based on a combination of theoretical and practical considerations.

\section{REFERENCES}

Aaron, H. (1966), 'The social insurance paradox', The Canadian Journal of Economics and Political Science, 32(3), 371-4.

Blommestein, H. (2001), 'Ageing, pension reform, and financial market implications in the OECD area', CeRP Working Paper No. 9, Turin (Italy).

Bodie, Z. (1990), 'Pensions as retirement income insurance', Journal of Economic Literature, 28(1), 28-49.

Boeri, Tito, A. Lans Bovenberg, Benoît Coeuré and Andrew W. Roberts (2006), 'Dealing with the New Giants: Rethinking the Role of Pension Funds', Geneva Reports on the World Economy, 8.

Breyer, F. (1989), 'On the intergenerational Pareto efficiency of pay-as-you-go financed pension systems', Journal of Institutional and Theoretical Economics, 145, 643-58.

Lusardi, A., and O.S. Mitchell (2005), 'Financial literacy and planning: implications for retirement wellbeing', DNB Working Paper, No. 78.

Verbon, Harrie A.A. (1989), 'Conversion policies for public pension plans in a small open economy', in Björn A. Gustafsson and N. Anders Klevmarken (eds), The Political Economy of Social Security, Amsterdam: Elsevier, pp. 83-95.

Visco, I. (2005), 'Ageing and pension system reform: implications for financial markets and economic policies', a report prepared at the request of the Deputies of the Group of Ten. 